\title{
ČLANCI/ARTICLES
}

KOSTA NIKOLIĆ, PhD, Principal Research Fellow

Institute of Contemporary History

Belgrade, Republic of Serbia

kostasnikolic@yahoo.com

NEBOJŠA STAMBOLIJA, Assistant Researcher

Institute of Contemporary History

Belgrade, Republic of Serbia

nstambolija@yahoo.com

pregledni rad

UDK: 355:929 Михаиловић Д.(093.2)

primljeno: 21. januar 2018.

94(497.11)"1941"(093.2)

prihvaćeno: 16. maj 2018.

https://doi.org/10.29362/ist20veka.2018.2.nik.9-36

\section{ROYALIST RESISTANCE MOVEMENT IN YUGOSLAVIA DURING THE SECOND WORLD WAR*}

\begin{abstract}
The Royalist resistance movement during the Second World War was represented by the Yugoslav Army in the Homeland (YAH), led by General Mihailović. It was an anti-Nazi military alliance based on patriotic sentiments created after the catastrophic defeat in the April 1941 war. What started as a small group of officers and soldiers of the former Yugoslav royalist army (a total of 26 men) who gathered on Ravna Gora on May 11, 1941, became a resistance movement that symbolized Serbian national ideology. History has remembered them as "Chetniks". The appearance of Mihailovic and his men met with enthusiasm in the "free world" as the first sign of resistance in occupied Yugoslavia. Praised and glorified at the beginning, they would be excluded from the Allied Coalition and stigmatized as "traitors" at the end of the war. The interpretation of the history of the YAH has been the most controversial issue of post-war Yugoslav historiography. Despite incontrovertible evidence of the YAH being a resistance movement, official narratives considered it Axis collaborators.
\end{abstract}

KEYWORDS: Yugoslavia, resistance, Chetniks, military strategy, communist ideology, Allies, Second World War, General Dragoljub Mihailović

In the years prior to the Second World War, Yugoslavia was drawn into the complex relations between the great European powers in which its national leadership did not manage to chart and impose an independent political option. The assassination of King Alexander I Karađorđević on October 9, 1934 in France triggered a series of events that dragged the Yugoslavia into the Second

\footnotetext{
* Article is part of project Srpsko društvo u jugoslovenskoj državi u 20. veku: između demokratije $i$ diktature (177016) that is financed by the Ministry of Education, Science and Technological development of the Republic of Serbia.
} 
World War. The legitimacy of this state of South Slavs was in question from its inception, but the Western democracies had neither the will nor the capacity to respond to this problem. ${ }^{1}$

Prince Paul Karađorđević was appointed regent for his 11-year-old nephew, Peter II. As regent, he felt constrained to undertake much needed and far-reaching reforms towards resolving national differences, above all the SerbCroat conflict over the constitutional structure of the state. Although Yugoslavia was politically oriented towards the Western democracies and supported the League of Nations, it found itself increasingly economically tied to Germany and Italy. The collapse of the Little Entente (an alliance between Yugoslavia, Czechoslovakia and Romania formed for the purpose of resisting a Habsburg restoration) had diminished Yugoslavia's regional influence. With the Anschluss of Austria, the German Reich became Yugoslavia's neighbour. Paul was soon forced to submit to Hitler's demands and align his policy with the Axis powers. During his visit to Berlin in June 1939, Paul became convinced that war in Europe was unavoidable and imminent. He therefore resolved to revive the talks with the Croats without delay in order to settle internal conflicts in his country. ${ }^{2}$

In July 1939, Paul visited London to shore up his relationship with the British Government. Immediately afterwards, he encouraged talks between his government and opposition leaders in Croatia, which led to the Agreement of August 26, 1939. However, rather than resolving the Serb-Croat conflict, the Agreement only served to intensify tensions between Serbs and Croats. For extreme Croatian nationalists, the Agreement was, at best, a small step towards independence, while for many Serbs too much had been conceded to the Croats.

When war engulfed Europe, Yugoslavia proclaimed its official neutrality. However, even under such circumstances Paul's views remained decidedly pro-Allied. The fall of France was a severe psychological blow as Yugoslavia could not hope for support from either Great Britain or the Soviet Union. In the summer and autumn of 1940, the position of Yugoslavia became very complex. Italy brought the battlegrounds closer to Yugoslav borders by occupying Albania and attacking Greece, while Romania and Hungary joined the Tripartite Pact in November. With Yugoslavia was surrounded, the state leadership faced a serious dilemma. Hitler called upon Paul to join the Tripartite Pact, but the Regent knew that the Serbs were overwhelmingly anti-German and pro-British. Joining Hitler's alliance was highly unpopular, especially in the Serb parts of Yugoslavia. Preservation of the state was important for safeguarding the numerous Serbs outside of Serbia. On the other hand, there was no realistic chance of the country challenging German's war machine.

In a quandary, Yugoslavia had no choice but to join the Tripartite Pact on March 25, 1941. Two days later Paul was deposed. The military coup,

\footnotetext{
${ }^{1}$ Vesna Drapac, Constructing Yugoslavia. A Transnational History (New York: Palgrave Macmillan, 2010), 143.

${ }^{2}$ Srdja Trifković, "Prince Pavle Karardjordjević", in: The Serbs and their leaders in the Twentieth Century, eds. Peter Radan and Aleksandar Pavković, (Sydney: Ashgate, 1997): 158-202, 179.
} 
planned and executed by a group of Serbian air officers of the Yugoslav army, led by General Dušan Simović, with assistance from British intelligence, was the ultimate expression of Serbian nationalism. The coup leaders proclaimed internal factors as being the coup's root cause, rather than dissatisfaction with Paul's foreign policy that had led to Yugoslavia's adherence to the Tripartite Pact. Motivation for the coup has long been a matter of historical controversy. However, it is indisputable that it was exclusively organized and supported by Serbs and that it reflected deep Serbian nationalist sentiment. ${ }^{3}$

The new government was in an even worse predicament than its predecessor. The government did not annul the pact of March 25 - a detail that was forgotten after 1945, when the mythology of the coup was created. ${ }^{4}$ Although Simović's government refused to ratify the Tripartite Pact, it did not openly reject it. It needed time to consolidate its authority, to patch up relations with the Croat Peasant Party, and to appeal for guarantees from the Allies. This strategy failed - Hitler flew into a fury at the news of the coup and the anti-German incidents in Belgrade that it provoked and on the same evening ordered that $\mathrm{Yu}-$ goslavia should be crushed military "as quickly as possible".

The British Secret Intelligence Service and the Special Operations Executive $^{6}$ already had prepared plans for a coup, and Foreign Secretary Anthony Eden, gave "provisional authority" to the British Minister in Belgrade "to do what he thought fit to further a change of Government, even at the risk of precipitating a German attack". ?

The coup in Belgrade on March 27, 1941 changed the course of, not only of Yugoslav, but also of European, history. In Marseille in France strangers laid banks of flowers upon the scene of the assassination in 1934 of King Alexander of Yugoslav and French Foreign Minister Barthous. ${ }^{8}$ The British Prime Minister Winston Churchill melodramatically declared that the Yugoslavia had 'found her soul'.' On the same day as the coup, Hitler issued Führer Directive No. 25 ordering the immediate invasion of Yugoslavia. Expecting help from the

\footnotetext{
${ }^{3}$ Peter Radan, "Constitutional Experimentation and the National Question in Interwar Yugoslavia", Istorija 20. veka, volume XXIX, no. 3, (2011): 25-38, 37-38.

${ }^{4}$ Sima M. Ćirković, The Serbs (Carlton, Australia: Blackwel Publishing, 2004), 268.

${ }^{5}$ Matteo J. Milazzo, The Chetnik Movement \& The Yugoslav Resistance, (Baltimore \& London: The Johns Hopkins University Press, 1975), 2-3.

${ }^{6}$ The Special Operations Executive (SOE), an independent branch of the "special services" tasked with nourishing general resistance within the occupied Europe. The SOE was formed on July 22, 1940, on Churchill's orders and it was placed under the direct control of Hugh Dalton, Minister of Economic Warfare. The creation of the SOE was intended to forge a liaison between Britain and European resistance movements. The SOE was designed to coordinate all subversive actions against the enemy overseas with the ultimate aim of "setting Europe ablaze" as Churchill put it.

${ }^{7}$ Christopher Catherwood, The Balkans in World War Two. Britain's Balkan Dilemma (London: Palgrave Macmillan, 2003), 157.

${ }^{8}$ Marta Iaremko, "Belgrade Coup D’État of March 27", Proceedings of History Faculty of Lviv University, Issue 15, (2014): 119-128, 125.

${ }^{9}$ Quoted in Winston S. Churchill, The Second World War, volume III The Grand Alliance (Boston: Houghton Mifflin Company, 1977), 148-149.
} 
Great Britain was unrealistic because there was neither the willingness nor capacity to do so. The situation was the same as it was before the coup - Great Britain was not ready to provide military help in case of an anticipated attack by the Germans. But, the British Prime Minister was still convincing the Yugoslav Government to stand up against Germany. ${ }^{10}$

The consequences of the coup were immediate and devastating for $\mathrm{Yu}$ goslavia. On April 6, 1941, the Axis launched its attack. German bombers appeared over Belgrade. This was called Operation "Punishment". Germany treated the attack on Yugoslavia as a showdown with Serbia and the opportunity to settle a score dating back to the Great War. The official statement of the German Government was marked by xenophobia and racism against the Serbian nation: "They are the same conspirators whose atrocities did not cease to infect the Balkans, who did not even stop short of killing monarchs, and who caused a worldwide war in 1914 with the assassination in Sarajevo, thus unleashing unprecedented calamities on the mankind."11

On the same day Germany invaded Greece. Hitler accused "British imperialism and Jewish financiers" of making plans to conquer the world, so Germany had to achieve "a true consolidation" in Europe. The Belgrade government was dubbed "a band of ruffians", whereas Britain was said to be "the greatest warmonger" of all time. ${ }^{12}$

Less than two weeks after the war began, on April 17, 1941, the rout was complete and the Yugoslav High Command was compelled to sign an unconditional surrender. There were examples of heroic and decisive defence by the Yugoslav army and German loses were not negligible. According to German data from May 4, 1941, the German casualties of war were as follows: dead 72 officers and 1,134 non-commissioned officers and soldiers; wounded - 206 officers and 3,695 non-commissioned officers and soldiers; missing - 53 officers and 495 soldiers; Therefore, or About half the Yugoslav armed forces 344,162 men (6,298 officers and 337,864 troops) - were captured. After most of the Croats and Macedonians captured troops were released, about 200,000 prisoners, largely Serbs, remained in camps in Germany. ${ }^{13}$

Yugoslavia was conquered and dismantled. In this process some of its regions sided with the Nazis. On April 10, 1941 the fascist Ustasha organization, led by Ante Pavelić, proclaimed the Independent State of Croatia as German troops poured into Zagreb. Bosnia and Herzegovina was included in this Nazi puppet state. The core of Ustasha ideology was fanatical Croatian nationalism, a fervent and mystical belief in the holiness and sanctity of the Croatian state. Its fascist tendencies were apparent. ${ }^{14}$

\footnotetext{
${ }^{10}$ Ibid, 154. Churchill to Simović, April 4, 1941.

${ }^{11}$ Military Archives, Belgrade (MA), collection The German occupying forces from 1941 to 1945, 2-2-45, Declaration of the German Government.

12 MA, The German occupying forces, 2-2-46, Hitler's order of the day April 6, 1941.

${ }^{13}$ MA, The German occupying forces, 2-1-13/1.

${ }^{14}$ Robert B. McCormick, Croatia Under Ante Pavelić: America, the Ustaše and Croatian Genocide (London \& New York: I.B Tauris, 2014), 9.
} 
Most Croats supported the idea of an independent Croatia after many centuries of foreign rule. The Ustasha regime was supported by the nationalist and anti-Communist Catholic Church in Croatia. ${ }^{15}$ The Croatian Government immediately introduced racist measures against their Serb, Jewish, and Roma minorities. A violent anti-Serbian campaign and mass terror, which soon reached genocidal proportions, started after a meeting between Pavelić and Hitler on June $6,1941 .^{16}$

Serbia was the only region of occupied Yugoslavia under the direct control of German military authorities. Her frontiers were reduced to those of before the Balkan Wars in 1912. Parts of southeast Serbia, as well as a part of eastern Kosovo, were annexed by Bulgaria. The eastern part of Srem was annexed by Croatia. Bačka was occupied and then annexed by Hungary. Banat became a separate administrative territory under the administration of the Banat Germans, while the remaining parts of Kosovo and Metohija, along with a portion of Sandžak, was included in the Italian protectorate of "Greater Albania". ${ }^{17}$

The Supreme Command of the Wehrmacht introduced a strict occupation regime in Serbia as a way of punishing the Serbs for the 27 March coup. The first military commander in Serbia was Air Force General Helmut Förster (General der Flieger). The German Ministry of Foreign Affairs and the Ministry of Cultural Development of Nations and Propaganda rejected any idea of fostering culture in Serbia because "Serbia has always been hostile to us. The only guideline in our attitude should be the protection of our own interests as an occupation force". 18

After the surrender of the Royal Yugoslav Army, King Peter and his government fled to Greece and continued their journey to Alexandria and then to Jerusalem where the Yugoslav Government-in-exile announced that Yugoslavia would continue the war against the Axis powers. On June 21, the King and his government arrived in London to take residence in the British capital. On June 26, Prime Minister Dušan Simović and Foreign Minister Momčilo Ninčić were received by Churchill. ${ }^{19}$

The British Government was reassuring: "We are renewing the comradeship that in the Great War carried us through tribulation to victory. We will conduct the war in common and make peace only when right has been vindicated and law and justice are again enthroned". ${ }^{20}$

${ }^{15}$ Ben Shepherd, Terror in the Balkans: German Armies and Partisan Warfare (Cambridge, Mass., Harvard University Press, 2012), 79.

${ }^{16}$ Kosta Nikolić, Istorija Ravnogorskog pokreta, I (Beograd: Zavod za udžbenike, 2014), 204-205.

${ }^{17}$ Velimir Terzić, Slom Kraljevine Jugoslavije 1941. Uzroci i posledice poraza. 2 (Beograd: Narodna knjiga, 1983), 547-604.

${ }^{18}$ Quoted in Walter Manoschek, ,, Serbien ist judenfrei “. Militärische Besätzungspolitik und Judenvernichtung in Serbien 1941/42, (München: Oldenbourg Verlag, 1995), 34.

19 Walter R. Roberts, Tito, Mihailović and the Allies, 1941-1945, (Durham: Duke University Press, second edition, 1987), 20; John R. Lampe, Balkans into Southeastern Europe, 19142014 (New York: Palgrave Macmillan, second edition, 2014), 151-152.

${ }^{20}$ Quoted in V. Drapac, Constructing Yugoslavia, 155. 


\section{Creating a Resistance Movement}

The Serb nation had a long history of fighting against foreign occupiers. Due to the rapid collapse of Yugoslavia and the ensuing operations in Greece and the Soviet Union, many Yugoslav army officers and soldiers were not captured. ${ }^{21}$

The nucleus of what later became a national resistance force was a small group of officers and non-commissioned officers of the Yugoslav royal army who refused to surrender at their post near the town of Doboj in northern Bosnia. Under the command of General Staff Colonel Dragoljub Mihailović, ${ }^{22}$ who at that time was Deputy Chief of Staff of the Yugoslav Second Army, these men retreated into the hills. Their aim was to move to the mountainous interior of Serbia where they hoped to find other parts of the Yugoslav army whom they would join and with whom they would continue the fight against the enemy. ${ }^{23}$

After the defeat of the Yugoslav army, Mihailović and his men gathered at the plateau of Ravna Gora in Western Serbia on May 11, 1941. The area was well known to Mihailović, who had fought there during the Great War. By calling his organization the "Chetnik Detachments of the Yugoslav Army" Mihailović was apparently trying to do two things. The first was to imply that his men belonged to the regular army, which would give them some protection under international law and would give him the authority to recruit in the name of the exiled government. The difficulty with this was that the army had performed shamefully during the April war and there was a danger that it retained very little respect. However, it was hoped that this would be overcome by appealing to the Serb popular imagination and its sense of a heroic past.

In the first days of the creation of the resistance movement, Mihailovic pointed out the need for secret organizing, civil disobedience and the harmfulness of early actions. He stated that the Kingdom of Yugoslavia never ceased to exist, and that although the first battle had been lost, the war had not yet been lost. He called upon all Yugoslavs to obey eventual calls for mobilization by his Supreme Command. He envisaged the establishment of secret organizations that would gather all Yugoslav patriots.

\footnotetext{
${ }^{21}$ See Vjeran Pavlaković, "Yugoslavia", in: European Resistance in the Second World War, eds. Philip Cooke and Ben H. Shepherd, (Barnsley: Pen \& Sword Praetorian Press, 2013), 213-242.

22 Dragoljub Mihailović (1893-1946) had served with distinction in the Balkan Wars and on the Salonika front in the Great War. He was awarded the Gold Medal for Courage and the Order of White Eagle. In the interwar period he held a series of staff posts. In 1935 he was appointed Military Attaché in Sofia and from May 1936 he held the same post in Prague. He was later the Professor of Tactics at the Higher School of the Military Academy in Belgrade. In 1939 Mihailović was punished with 30 days confinement to barracks for advocating a radical revision of the Yugoslav defence plans. However, General Milan Nedić, the Yugoslav Minister for the Army and Navy, resigned his post in November 1940 and his successor, General Petar Pešić, spared Mihailović the full punishment. In the late 1930s, Mihailović appears to have developed a strong anti-Nazi attitude. He maintained close relations with Colonel C.S. Clarke, the British military attaché in Belgrade. See: Bojan Dimitrijević, General Mihailović. Biografija (Beograd: A.L.X, 1996).

23 Jozo Tomasevich, The Chetniks. War and Revolution in Yugoslavia, 1941-1945 (Stanford, California: Stanford University Press, 1975), 122.
} 
The concept of resistance was based on assessments of German military strength, while military strategy, inherited from the former Yugoslav army, included the establishment an army intended as a striking force to be used in a prospective general uprising against the foreign enemy. This concept was primarily meant to avoid heavy losses amongst the Serbian population. The fighters who represented the core of the illegal organization were supposed to arouse the people's fighting spirit and to perform minor diversions and acts of sabotage useful for the common Allied cause without provoking German reprisals. Their instructions were to obstruct communications along the Belgrade-Niš-SofiaSalonica railroad line which was of vital importance to the German forces. In addition to this, the guerrilla fighters were supposed to protect the population against looting and to serve as a constant threat to German and quisling forces. ${ }^{24}$

Mihailović followed the policy laid down by the Yugoslav Government on July 22 in its declaration read over the BBC admonishing the Yugoslav people to avoid premature engagement with the enemy and to wait for directions from London. ${ }^{25}$ Nevertheless, one Chetnik detachment under the command of Lieutenant-Colonel Veselin Misita liberated the town of Loznica on August 31, 1941. More than ninety German soldiers were captured on that occasion, but Misita was killed in action. ${ }^{26}$

Loznica was the first town in Serbia liberated from German occupation. The joint Partisan-Chetnik uprising against the German occupation forces followed. However, the objectives of Tito and his communists, on one hand, and of Mihailović and other Yugoslav officers, on the other hand, were totally incompatible. The Yugoslav Communists waged a revolutionary war carried out with violence. Their most important war goal was to build a new social and political regime. This goal was to be achieved through parallel anti-German resistance and civil war actions.

There was also the issue of German reprisals in which, from the outset of the resistance, 100 civilians were executed for each German soldier that was killed and 50 were executed for each German solder that was wounded. Many Austrianborn Nazis, Hitler among them, certainly regarded the Serbs with great contempt. This was, to a considerable extent, a legacy of the Great War. It was founded on hatred, caused by the losses and humiliation of the Austro-Hungarian troops in the campaign against Serbia's armies in all three attempts to vanquish Serbia in 1914. ${ }^{27}$ During the autumn of 1941, the Germans launched an all-out attack on both resistance movements in an effort to crush the rebellion once and for all. Serbian towns and villages were soon recaptured by the Germans which was followed by unprecedented retaliations against civilians. On October 14 the Germans shot 1,755 civilians in Kraljevo. On October 21, 2,778 men, many of whom were stu-

\footnotetext{
${ }^{24}$ MA, The Chetnik's archives, (MA, CA), 16-1-2.

${ }^{25}$ W.R. Roberts, Tito, Mihailovic and the Allies, 26.

${ }^{26}$ MA, The German occupying forces, $44 \mathrm{H}-1-6$, the Report of the Staff of $718^{\text {th }}$ German Infantry division.

${ }^{27}$ B. Shepherd, Terror in the Balkans, 34-35.
} 
dents driven out of their schoolrooms, were assembled just outside the town of Kragujevac and gunned down. ${ }^{28}$ Dimitrije Đorđević reasonably concluded that resistance was not the issue anymore but rather, the suicide of the nation. ${ }^{29}$

The Communists were not disturbed by these events. The people escaping from such punitive reprisals were easily recruited into their units. These tragedies broke down the fibres of normal society and created favourable conditions for those bent on revolution in a war-torn country. The Partisans pursued a clear objective throughout the chaos of the civil war - assuming power and carrying out a communist revolution. ${ }^{30}$

Haunted by the memory of what had taken place during the Great War, the reprisals led Mihailovic to conclude that continuation of the resistance would amount to "national suicide". In fact, the unprecedented German reprisals and genocide performed over the Serbian population induced Mihailović to negotiate with German occupation authorities. A meeting between LieutenantColonel Rudolf Kogard, the head of German Military Intelligence in Belgrade, and Mihailović took place on the evening of November 11, 1941. Mihailović offered to cease hostilities in the towns and along the major communication lines. He also asked for weapons to fight against Partisans. But Kogard delivered an ultimatum to Mihailović in which he demanded Mihailović's immediate and unconditional surrender. Mihailović refused and the meeting ended in failure. ${ }^{31}$

The uprising in Serbia during the summer and autumn of 1941 did not inflict serious losses to the German army (approximately 200 German soldiers were killed and 400 were wounded). German documents show the brutality with which the Wehrmacht handled the Serbian rebellion. By the end of December 1941 around 4,000 insurgents had been killed in fighting and 35,000 hostages had lost their lives. Mihailović concluded that the results did not justify such immense sacrifices. His main objective became the preservation of his forces. In order to preserve his army and the civilians he had to considerably reduce his military activity. He was encouraged in this policy by British military authorities. The country became relatively calm for a certain period of time.

During this confused period, Mihailović was appointed the leader of the national resistance in Yugoslavia on November 15, 1941. General Simović announced this on Radio London but added the warning that the right moment for the "decisive" fight had not yet come. Simović called upon all people who were fond of freedom, "especially those brave sons who have risen to defend that freedom with their arms in their hands to unite in the common struggle against the occupiers and satraps by rallying under the command of Draža Mihailović, the commander of all the Yugoslav armed forces in the country". ${ }^{32}$

\footnotetext{
${ }^{28}$ Heather Williams, Parachutes, Patriots, and Partisans. The Special Operations Executive and Yugoslavia, 1941-1945 (London: C Hurst \& Co Publishers Ltd, 2003), 60-61.

${ }^{29}$ Dimitrije Đorđević, Ožiljci i opomene, I (Beograd: BIGZ, 1994), 306-307.

${ }^{30} \mathrm{H}$. Williams, Parachutes, Patriots, and Partisans, 60-61.

${ }^{31}$ K. Nikolić, Istorija Ravnogorskog pokreta, I, 155-156; M. Milazzo, The Chetnik movement, 37-38.

32 Službene novine Kraljevine Jugoslavije, 1. 12. 1941, 10.
} 
This policy was accepted by the British Government - Mihailović was to be supported and Moscow was to be prodded to influence the Partisans to collaborate with him. ${ }^{33}$ Mihailović renamed his forces as the Yugoslav Army in the Homeland, a name that would be retained until the end of the war. It reflected the effort to maintain the continuity of pre-war Yugoslavia and the desire that the Chetnik guerrilla forces would be transformed into a regular army.

At the end of 1941, Simović strove to attach particular importance to what was going on in Yugoslavia and he suggested to King Peter to promote Mihailović to the rank of general and include him in the government-in-exile. This manoeuvre was designed to confirm that, although the Yugoslav army capitulated in April 1941, part of that army never consented to surrender and continued to fight. Such an interpretation was important to the Yugoslavs because it allowed them to insist on the Allies granting Mihailović's forces the status of a regular army which had certain rights under international law. On December 7, the Yugoslav Government promoted Mihailović to the rank of Brigadier General. On January 11, 1942, Mihailović was appointed the Minister of Army, Navy, and Air Force in the new Yugoslav government headed by Slobodan Jovanović, a well-known law professor and historian. ${ }^{34}$

Creation of a new military organization was finalized in June 1942. On June 10, King Peter requested from Slobodan Jovanović that the Supreme command of the Yugoslav army should be transferred to the "occupied Homeland", and to place Mihailović as its Chief of Staff. At the same time, Mihailović was promoted to the rank of Army General on June 17. ${ }^{35}$

\section{Civil War}

A very important factor in assessing the character of the royalist resistance was the appearance of the Communists and their desire to destroy the pre-war order and to build a new one. The conflict between these rival resistance forces in the midst of Axis occupation was the cause of ever-increasing concern amongst the Allies, particularly the British.

The ideological divide was deepened by religious differences between the various peoples of Yugoslavia and by the genocide against the Serbs in the Croatian state. Together, these factors hampered the resistance against fascism. There is no doubt that the gravest consequences emanated from the civil war between the Royalists and the Partisans. The civil war, which broke out during the uprising, increased the discord between the country's internal forces, and decided the further course of the war in Serbia and Yugoslavia, leaving lasting consequences that were impossible to remediate. The events of the autumn of 1941 plunged the two resistance movements into an insuperable mutual antago-

\footnotetext{
${ }^{33}$ Military Archives, collections: The Documents of the Foreign Office, 1-1-46, Foreign Office to War Cabinet on November 16, 1941.

${ }^{34}$ Simon Trew, Britain, Mihailović and the Chetniks, 1941-42 (London: Macmillan, 1998), 100-101.

${ }^{35}$ Službene novine Kraljevine Jugoslavije, 8. 8. 1942.
} 
nism from which they emerged as bitter opponents, more intent on destroying each other than on fighting the common enemy.

The civil war waged in Serbia during Second World War was a specific phenomenon. Its peculiarity is recognized by the conditions in which it evolved, by divisive developments, and by the hatred it produced. Instead of occurring in a free country, it took place under multiple foreign occupations. It was not waged by regular troops, but rather by guerrilla units in various ways: in places through frontal combats, and elsewhere in the form of brutal guerrilla or terrorist actions. Extreme passion to destroy the opponent physically was also evident. The conflict between the Partisans and the Royalists produced the war's most serious consequences. This conflict lasted until German troops withdrew and continued in a particular form for several years after the end of Second World War. It was reflected in a repression pursued by the victor's mass liquidation of the defeated opponent and the brutal showdown with its followers.

One of the advantages enjoyed by the Partisans in the civil war was that the nature of their political program was unknown to the rival movement, or by the public. In fact, Yugoslav communists had, before Second World War, enjoyed certain level of sympathy from the liberal public, as youth idealism was attributed to them and the ordinary people always had sympathy for those harassed by the police. In public they were most frequently condemned by the members of Dimitrije Ljotić's movement, which was extremely unpopular, thereby making the communists relatively well accepted when resistance to German occupation began. The Yugoslav Army in the Homeland was supervised by the young officers feeling that their combat involvement was their military and patriotic duty, without any particular ideology or political goal as stimuli. They just wanted to liberate their country, while hoping that the new state would be better and more just than the previous one. On the other hand, the Partisans were led by a fanatically political party with a few thousand convinced revolutionaries who had no doubts about their objectives and followed a simple, but efficient, ideology.

One of the fundamental mistakes of Yugoslav Army in the Homeland was using repressive measures against communists and their followers. Almost as a rule, each pursuit of the Partisans caused their collaborators to be oppressed, irrespective of the truth of allegations made against them. Many Royal officers thought that communism in Serbia could be most effectively eradicated by persecution and intimidation of the Partisans and their supporters. However, this only produced adverse effects. Communist ideas were a big unknown for the Serbian people and, being demagogic and attractive, frequently close to religious principles, and promising social paradise. The perception of the "Red Terror" was not apparent elsewhere in Yugoslavia, and it is questionable how effective it would have been if it had been. The Yugoslav Army in the Homeland was unable to adequately counter communist propaganda, so they sought to fight with "fire and the sword".

The position of the Yugoslav Army in the Homeland was further exacerbated by its conflict with right-winged "traitors" (Ljotić's volunteers), a con- 
flict fought with the same ferocity as that with the communists. Although sometimes some of the Chetniks detachments collaborated with detachments of the wartime Serbian government of General Nedić, they were never able to secure a regular inflow of assistance in the form of weapons. Furthermore, Mihailović's forces were continuously subjected to assaults by the Axis Powers' forces from mid-1942 until mid-1944.

On the other hand, the communists in Serbia were a minority at the end of 1941. They faced considerable discontent from the people because of the Partisan's misguided tactics that provoked German reprisals. As Second World War approached its end the Partisan movement kept growing, mostly due to support from the youth in rural southern Serbia, where the population suffered from the violent behaviour of the Bulgarian military forces since the latter's occupation of that region in 1941. Very little was known in the towns about the Partisans. Nevertheless, there were many potential Partisan sympathizers among the youth in these towns, especially among students from Belgrade who found the goals of the Yugoslav communists attractive. And yet, they only began to adopt them when the outcome of the Second World War was obvious, as they did not want to risk their lives or to jeopardize their future.

On the other hand, the Yugoslav army, constituted mostly of peasants who had joined as volunteers, had the general traits of a defence militia organized according to the territorial principle. It was difficult to motivate these soldiers for action outside their immediate environment, away from their homes, farms and villages. Such an army is often characterized by anarchic tendencies and poor discipline, which corresponds to the general Serbian attitude to warfare. Nevertheless, apart from Polish Armia Krajowa, the Yugoslav Army in the Homeland was the most powerful non-communist army in occupied Europe, far ahead of organizations such as the one led by Colonel Napoleon Zervas in Greece. ${ }^{36}$

\section{The ideology}

The Royalist movement which developed in occupied Yugoslavia, with the sole exception of Slovenia, was a traditional royalist and national Serb force. Despite the official Yugoslav label and the participation of some non-Serbs, the Royalists were essentially a Serb national force from the outset. The real Royalist focus was on Serb matters. In the ethnoreligious conflict, the Royalists looked to the Serb side, and before long, they started equating themselves with Serbdom. This does not imply, however, that the Royalists were anti-Yugoslav as such, or that they did not want to restore Yugoslavia - albeit on their own terms - after the war. This meant that the creation of a Serb territorial unit, was the first priority for the Royalist. The restoration of Yugoslavia was a secondary concern, and then only after the successful completion of all Serb-related matters. For the Royalists, the intention was to restore Yugoslavia at the end of the

\footnotetext{
${ }^{36}$ D. Đorđević, Ožiljci i opomene, I, 312.
} 
Second World War along the lines of what they believed should have been done in 1918, thereby correcting a number of "historical mistakes". ${ }^{37}$

During the Second World War there were three parallel conflicts in occupied Yugoslavia. First, a resistance struggle against the Axis, second, a communist-royalist civil war and third, a regional ethnoreligious conflict made possible by the wartime circumstances. The Yugoslav Army in the Homeland was unique among wartime guerrilla groups in that it fought in all three: as the extension of the Yugoslav army in the resistance struggle, in the civil war as royalists, and in the ethnoreligious conflict as a Serb territorial force in areas with a mixed population. The ethnoreligious conflict, a distinctive "war within a war", had a profound transformative influence on Royalist wartime strategy and ideology and a lasting impact on the region's future. The civil war with the Partisans also had a great impact on Royalist wartime strategy. Once combined, these elements paint a picture of Mihailović's wartime resistance movement as an anticommunist, royalist, Serb territorial military force in areas with a heterogeneous population, and an anti-communist royalist guerrilla in Serbia and Montenegro. ${ }^{38}$

The original Royalists' intent was to simply be a guerrilla resistance group, organizing in the shadows in preparation for a general uprising when the Allies reached the Balkans. This was their initial purpose - their engagement in the other two conflicts was purely reactive, being neither planned nor desired. The Royalists wartime position was difficult, challenging and full of contradictions. They were, first and foremost, a resistance group. However, both the ethnoreligious conflict and the civil war with the Partisans pushed them into collaboration in certain areas with their enemies, primarily with the Italian army in the notorious Independent State of Croatia, where the Serbian population was a target for Ustasha genocide.

The collaboration with the Italians had its roots in changes in Italian politics. Most independent researchers agree that the intention of the Second Italian Army, commanded by General Vittorio Ambrosio, was to give support to all those who were victims of the Ustasha persecution, principally the Serbs and the Jews. Ambrosio and other Italian officers felt it was their duty to act as saviours of those running away from the "Croatian butchers".

Thus, the anti-communist collaboration of the Serbian royalists with the Italians cannot be viewed and interpreted beyond its inevitability, which was conditioned by a series of wartime circumstances. This collaboration had the character of self-defence counterweight aimed at providing a sanctuary for victims of Ustasha crimes. The change in Italian policy in the summer of 1941 was of major significance for the further course of the Second World War in Yugoslavia. Most insurgents felt that their struggle had inflicted a heavy blow to the Ustasha regime, which it considered as its major worst enemy. Accordingly,

\footnotetext{
${ }^{37}$ Aleksandar Petrovic, The Transformation of Mihailović's Chetnik Movement: from Royalist Yugoslav Forces to Serb Nationalist Guerrillas, (Ph.D. Thesis, Burnaby, British Columbia: Simon Fraser University, 2011), 302-303.

${ }^{38}$ Ibid., 360.
} 
under the impact of the suffering of the people, some Serbian commanders and popular leaders made settlements with the Italians, and the latter felt free, in their occupation zones, to provide sanctuary for the persecuted Serbs and to nourish them and supply them with the arms. ${ }^{39}$

The Royalists were nominally the armed forces of the Kingdom of $\mathrm{Yu}$ goslavia and were officially recognized as such by the Yugoslav Governmentin-exile and the Allies until the summer of 1944. However, in areas of occupied Yugoslavia with a mixed population, at the geographical fringes of Serbia and Montenegro and particularly in the Independent State of Croatia, the Royalists essentially became a Serb territorial paramilitary force, protecting villages in the ethnoreligious conflict against the Ustashas, Muslim and Albanian militias, and engaging in retaliatory attacks against nearby non-Serb settlements. It should also be noted that, as the war dragged on, the conflict with the Partisans gradually assumed ascendancy over both the resistance struggle and the ethnoreligious conflict, consuming the Royalist movement's energy and deflecting its attention. ${ }^{40}$

The decisive factor which influenced the formation and development of the Royalist resistance movement was the quick and inglorious defeat of the Yugoslav Army in April 1941. The core of the resistance movement which was created at Ravna Gora, from its very beginning, avoided any contact with prewar politicians who were blamed for the April debacle and the two-decade long mis-management of the country, and especially for betraying traditional Serbian ideals. The tone to this kind of thinking was given by Mihailović. As an officer of the Yugoslav Army he thought that he should work without the politicians and that his men should make direct contact with the people where they would find moral and material help.

However, when it was realized that this was not achievable, Mihailović launched an initiative to cooperate with the politicians, but only with those who had not participated in the pre-war regime. According to Mihailović, there was a need to create one political board. When the leaders of the Agricultural Party found out about Mihailović, they immediately made contact with him. Under the influence of Lazar Trkulja, the secretary of the party and Mihailović's close friend, at the start of August of 1941 Mihailović ordered the Belgrade headquarters of the Yugoslav Army in the Homeland to form a board together with Trkulja which would contain representatives of political, cultural and youth groups as an advisory body.

The board was made up of members of the Serbian civil opposition parties - the Radical, Democratic and the Agricultural Parties and had the intention of becoming the political wing of Mihailović's movement. Such a development was immediately opposed by Dragiša Vasić, a renowned writer, cultural worker and one of the vice-presidents of the Serbian Culture Club. His idea was to create a completely new people's movement, where "there would be no place for

\footnotetext{
39 See H. James Burgwyn, Empire on the Adriatic: Mussolini's Conquest of Yugoslavia 19411943 (New York: Enigma Books, 2005).

${ }^{40}$ A. Petrovic, The Transformation of Mihailović's Chetnik Movement, 366.
} 
failed politicians". He was the first to suggest the name the Ravna Gora Movement which as an original and self-made organization with a totally new conception and method of work with a program for the creation of a new state and society. The board in Belgrade never came to life because the Gestapo arrested many of its members in the autumn of $1941 .^{41}$

Besides Dragiša Vasić, Mladen Žujović, the second vice-president of the Serbian Culture Club, played a crucial role in the orientation towards creating a completely new people's movement. He perhaps influenced Mihailović the most to accepting the view that a military organization needed the support of civil and political authorities who would be united in one central body - the Central National Committee. The Committee was supposed to consist of the leaders of Serbian political parties who remained in the country, representatives of patriotic associations and distinguished public workers. ${ }^{42}$

Mihailović emphasized that the Central National Committee could not have a party-political character, but rather, a national one. Its members could only be "honourable and honest people" with a reputation of authority before all cultural and educational workers in their region who were "nationally correct and meritorious for the overall people's goals". Mihailovic thought that they would have to be an example of the arrival of a new era and a new road to be taken by the people. Mihailović's movement, from its very beginning, started profiling the struggle for thorough social and political reforms. In historical sources the term "National Ravna Gora Revolution" is mostly used, which means that it is incorrect to suggest that Mihailović opted for a fictional revolution pressured by the work of the adversarial movement. ${ }^{43}$

For the Royalists, the ideological challenge of participation in the ethnoreligious conflict was profound. In the light of widespread persecution of the Serbs in occupied Yugoslavia, particularly in the Independent State of Croatia, Royalist leaders faced a dilemma over the ultimate aim of the struggle: was the goal to restore Yugoslavia or establish the 'United Serb Lands'? As a direct continuation of the royal Yugoslav army, the post-war restoration of the Kingdom of Yugoslavia was certainly a Royalist obligation. They were fighting for the return of the King and his exiled government. However, there had been widespread dissatisfaction with the state of affairs in interwar Yugoslavia and shock at the wartime collapse and subsequent events.

In the Royalist movement the was a specific and dominant national feeling that Serbia has provided too much in creation of Yugoslavia - their sovereignty, "glorious traditions and history", and a victorious army that were abandoned too easily. Ideas for the political and social structure of post-war Yugoslavia were announced at the People's Congress, held at the village $\mathrm{Ba}$ from January $25^{\text {th }}$ to the $28^{\text {th }}, 1944$. This Congress was attended by more than

\footnotetext{
${ }^{41}$ K. Nikolić, Istorija Ravnogorskog pokreta, II, 241-243.

42 Mladen Žujović, Ratni dnevnik 2. Jugoslavija u II svetskom ratu (jun 1942-april 1944), (Vrnjačka Banja: Interklima-grafika, 2004), 9.

${ }^{43}$ K. Nikolić, Istorija Ravnogorskog pokreta, II, 241-252.
} 
300 representatives from all of Yugoslavia and all political parties, except Communists, participated. Živko Topalović, the pre-war leader of the Yugoslav Socialist Party, played the main role in the organization of the Congress. The Yugoslav Democratic People's Union was formed and the legitimacy of the Karađorđević dynasty recognized. Yugoslavia was to remain a monarchy, but one based on new, federal principles. The country would be divided into three federal units - the Serbian, Croatian, and Slovenian. Bosnia and Herzegovina would be within the Serbian federal unit. The parts of Bosnia and Herzegovina inhabited by Muslims would be granted substantial religious and political freedom to establish cultural and religious ties with Islamic countries. The intention was that the creation of a Serbian federal unit would help prevent the repetition of "past mistakes", as well as acting as a safeguard against a renewed genocide of the Serbs. This Congress was a democratic step forward in the ideology of the Ravna Gora movement, but unfortunately, it happened too late - the fate of postwar Yugoslavia has already been decided two months earlier in Tehran. ${ }^{44}$

\section{Yugoslav Army in the Homeland and the Allies}

The battle for control of Yugoslavia proved to be an important front for the Allies when the Allied efforts in Europe are examined. Resistance manifested itself in several European nations, which included the royalists of General Mihailović and the Yugoslav Partisans. Churchill and the Allies were quite aware of this and so they were apt to support Mihailovic during the initial stages of the resistance. When Mihailović established radio contact with the British services in September 1941, romantic articles started being published in the free world press extolling the virtues and exaggerating the prowess of Mihailović as a resistance leader. The Political Warfare Executive ${ }^{45}$ was keen to capitalize on this heroic image of Mihailović. In the early days of the war this was all that was wanted from Mihailović's forces - the fact of their existence was enough. By the spring of 1942 Mihailović had been built up as the hero of the European resistance. For the British, Mihailović was useful for propaganda purposes, not just in Britain, but also in the Nazi "European fortress". Mihailović was also viewed as a bastion of order and continuity compared with the perceived threat of the communist movement. ${ }^{46}$

\footnotetext{
44 The delineation of borders between the Serbian and Croatian units was to be done after the war and was envisioned as possibly including the mutual exchange of citizens. Each federal unit was conceived as having its own federal assembly and significant political autonomy within the federation. The federal assembly was to have two governing bodies, consisting of elected and delegated representatives. Besides the dynasty, other shared institutions were to be the army, the ministry of transportation, foreign and financial policy, together indicating an almost confederate concept of government (Kosta Nikolić, Milan Vesović, Ujedinjene srpske zemlje. Ravnogorski nacionalni program [Beograd: Vreme knjige, 1996], 67-70).

45 The Political Warfare Executive, established in August 1941, was Britain's principal organization for the conduct of psychological warfare against Nazi Germany. After a dispute with the Ministry of Information and the Foreign Office, SOE's propaganda functions were transferred to the Political Warfare Executive, which was under Foreign Office control.

${ }^{46}$ H. Williams, Parachutes, Patriots, and Partisans, 46, 244.
} 
Britain and the Soviet Union found it difficult to pursue a common policy towards the two resistance movements in Yugoslavia for the purpose of welding them into a single organization because both Great Powers had their own particular interests. The Soviet Government was clear in treating Yugoslavia as part of its sphere of interest.

The first official Soviet attack on Mihailović occurred on August 3, 1942, when Solomon Lozovsky (Соломон Абрамович Лозовский), the Deputy People's Commissioner for Foreign Affairs and the Head of the Soviet Information Bureau, handed to Stanoje Simić, Yugoslav Minister to the Soviet Union, a memorandum that alleged that Mihailović was collaborating with the Axis powers. ${ }^{47}$ At the same time Moscow started disseminating communist propaganda throughout the world. The conflict between the Partisans and Chetniks was made public with the special emphasis on the Chetniks' "guilt" and their "cooperation" with the enemy. On the other hand, the importance of the Partisan struggle and its contribution to the general Allied cause was widely publicized.

It is to be noted that the open change in Soviet policy coincided with the recruitment of the first group of Canadian-Yugoslav Communists to serve as British intelligence officers in Yugoslavia. This was the operation, carried out under the auspices of the Sir William Stephenson's British Security Coordination office in New York (which represented all of Britain's wartime secret services), and which enlisted the help of the American and Canadian communist parties in recruiting Yugoslav immigrants for training as organizers of guerrilla warfare for eventual dispatch to their homeland. These recruits have usually been identified as Canadian-Croats. In fact, they were residents of the United States as well as Canada and included Serbs, Montenegrins and Slovenes in addition to Croats. ${ }^{48}$

The change in Soviet policy was brought about because the USA had raised the issue of aid for Mihailović at the highest level during King Peter's visit from June 19 to July 23, 1942. The first meeting between President Roosevelt and King Peter was attended by Churchill. Roosevelt promised that aid would soon be sent to Mihailović. President Roosevelt's spokesman praised the courageous achievements of Mihailović and his daring men as "an example of spontaneous and unselfish will to victory". 49

Accusing Mihailović of anti-Allied activity/collaborating with the Axis was designed to push Washington into following Soviet policy towards Yugoslavia. ${ }^{50}$ From this moment onwards, the British and American policies towards the resistance movements in Yugoslavia were increasingly conditioned by Anglo-American relations with the Soviet Union. Postponing the opening of a sec-

\footnotetext{
${ }^{47}$ MA, collection The Royal Yugoslav Government in exile, 29-1-57.

${ }^{48}$ Mark Wheeler, "Resistance from abroad: Anglo-Soviet efforts to coordinate Yugoslav resistance, 1941-1942“, in: Special Operations Executive. A new instrument of war, edited by Mark Seaman, (London and New York: Routledge Taylor \& Francis Group, 2006): 103-122, 105.

49 Službene novine Kraljevine Jugoslavije, 6. septembar 1942.

50 Валерий Теодорович Юнгблюд, Алексей Александрович Костин, “Американское восприятие Советской политики в отношении Югославии в 1942-1945”, Известия Уральского федерального университета Том 120, nо. 4 (2013): 71-85, 74.
} 
ond front in Western Europe left Britain and the USA exposed to constant Soviet accusations of not pulling their weight in the war. This produced a fear that the Soviet Union might conclude a separate peace with Germany. ${ }^{51}$

This event would have been catastrophic for the Western Allies as the Germans would then have been able to concentrate a significant number of divisions against the Allies on the Western Front, jeopardizing any chances of a successful invasion. As such, it was necessary not to upset the Soviets and have them bow out of the war. This is one example where Yugoslavia came into play: "The British and Americans did not want to make the Soviets angry over Yugoslavia and force the Soviets to change their policy once it was realized that they would have their influence over much of Eastern and Central Europe." 52

As Williams has noted, it may have been no coincidence that the antiMihailović article in the Soviet War News appeared on August 12, 1942, the very day that Churchill arrived in Moscow to explain to Stalin in person that there was to be no second front in Europe till 1943, a task Churchill described as "like carrying a large lump of ice to the North Pole". 53 According to confidential documents of American Department of State, the Yugoslav government at London tried to persuade the Soviets to suspend their activities in Yugoslavia. They got the answer that if anything was being done there it was the "work of the Comintern, for which the Soviet Government is not responsible". 54

As the Soviet propaganda campaign against Mihailović continued, the Foreign Office and the British Army became increasingly concerned about their differences with Moscow with regard to Yugoslavia. It was necessary to settle those differences and the issue centered on how to reconstruct Yugoslavia on completely new foundations. From Summer 1942 onwards, the Foreign Office officials started to formulate principles for a new strategy for Yugoslavia. Those were: a) the Serbian pre-war "hegemony" had been a "chronic damnation" of Yugoslavia and, to a large extent, responsible for the country's collapse in April 1941 ; b) Despite the past, most Yugoslavs desired a reconstruction of their country and British policy had to try to strengthen "the moderate forces" among the Yugoslavs prepared to fight against the enemy. Thus, it was necessary to find a formula that could resolve the old dispute between the Serbs and Croats in order to induce the latter to abandon Pavelić and support the idea of Yugoslavia's reconstruction. ${ }^{55}$

Throughout 1942, the British-Yugoslav relationship would continue to ride waves of tension. In the course of 1942 the British began to question the

${ }^{51}$ H. Williams, Parachutes, Patriots, and Partisans, 246.

52 Jason Alan Shambach Csehi, When Two Worlds Collide: The Allied Downgrading of General Dragoljub "Draža" Mihailović and Their Subsequent Full Support for Josip Broz "Tito", (MA., Thesis, Kent State University, 2009), 104-105.

${ }^{53}$ H. Williams, Parachutes, Patriots, and Partisans, 85.

${ }^{54}$ National Archives Washington, General Records of the Department of State, Record Group 59 (NAW, SD), Division of European Affairs, August $6^{\text {th }}, 1942$.

${ }^{55}$ Kosta Nikolić, Saveznici i pokreti otpora u Jugoslaviji 1941-1945 (Beograd: Zavod za udžbenike, 2009), 70-72. 
reliability if the Chetniks and to doubt the loyalty of Mihailović but maintained some ties with him for a year after that. By far the most important role in bringing about the abandonment of Mihailović was played by the Special Operations Executive. It was quite unknown to Churchill and the other Allied leaders how deeply infiltrated were communist operatives in the SOE. They penetrated the large SOE office in Cairo which supervised Balkan missions and helped steer SOE assistance towards Communist resistance factions. In Greece, the SOE armed several thousand agents but found that Communist partisans used this weaponry to eliminate rival Greek forces rather than the Germans. ${ }^{56}$

The same process was also happening in Yugoslavia, the difference being the two was that Great Britain supported royalists in Greece, but communists in Yugoslavia. One in particular, James Klugmann, would play a large part in the change in policy towards Mihailović. It should be noted that Klugmann belonged to the same group of Soviet agents as did Guy Burgess, Donald Maclean and Kim Philby, all of them students of the University of Cambridge, who became agents of the Soviet Union during the early 1930s. Agents in the Cairo office were in the position to alter, fabricate, or obscure information. Since the recipients and the senders were not privy to this sort of covert activity, they did not know and did not suspect that they were in receipt of false intelligence and other information. ${ }^{57}$

The campaign against Mihailović rested on three basic charges: first, that his forces were inactive and ineffectual against the Axis; second, that many of his followers were engaged in active collaboration with the Italians and the Germans against the Partisans; and third, that Mihailović had lost most of his popular support, whereas Tito had overwhelming support among anti-Axis Yugoslavs. This was the substance of the first reports, sent out from the beginning of April 1943, by several intelligence teams of Canadian-Yugoslav Communists recruited to serve with the Partisan forces It also constituted the first of the reports sent out shortly afterward by the first British liaison officers with Tito's forces, Captain (later Lt. Colonel) William Deakin and Brigadier Fitzroy Maclean, who parachuted into Yugoslavia on May 27, 1943, and September 16, 1943, respectively. ${ }^{58}$

${ }^{56}$ Encyclopedia of Insurgency and Counterinsurgency. A New Era of Modern Warfare, edited by Spencer C. Tucker (Santa Barbara, California; Denver, Colorado; Oxford, England: ABCCLIO, LLC, 2013), 529.

${ }^{57}$ Roderick Bailey, "Communist in SOE: explaining James Klugmann's recruitment and retention", in: The Politics and Strategy of Clandestine War. Special Operations Executive 1940-1946, edited by Neville Wylie (London and New York: Routledge Taylor \& Francis Group, 2007): 66-89. In his latest book British historian Christopher Catherwood claims that the decision to switch support in 1943 from the Chetniks to Tito and his Communist partisans was based upon absolutely solid evidence and in Britain's best military interests. Catherwood considers that this was not the terrible mistake but one of Churchill's most significant and consequential decisions about Balkans in Second World War (Christopher Catherwood, Churchill and Tito: SOE, Bletchley Park and Supporting the Yugoslav Communist in World War II (Barnsley: Frontline Books, 2017).

${ }^{58}$ See David Martin, The Web of Disinformation: Churchill's Yugoslav Blunder (New York: Harcourt Brace Jovanovich, 1990). 
Maclean was not a career officer. An impulsive Scot, at 32 years of age, he had served eight years in diplomacy, "felt at home" in difficult political situations, and was a sufficient realist to appreciate the dimensions of Tito's past work and future potential. More importantly, he belonged to the British Establishment and was a Member of the Parliament. He was also a personal friend of Churchill, who appointed him as his personal representative, much to the annoyance of SOE and the Cairo military command. Maclean did not take long to make up his mind: Tito must be supported to the maximum of SOE's ability. ${ }^{59}$

For nearly two years, based either on the Adriatic island of Vis or in the Yugoslav interior, Maclean shared the fluctuating fortunes of Tito and the Partisans. He was constantly pointing out that Mihailović and his Chetniks were the "military wing of Greater Serb nationalism." Hence, in his view, the only possible support of British government should be directed toward the Partisans, not against them. Lavish assistance would help distancing Tito from Moscow and secure British influence in postwar Yugoslavia. The differences among its nations would be overcome due to the multi-ethnic character of the Partisan movement. ${ }^{60}$

A contemporary historian noted that after the conference in Tehran, the British Prime Minister would not have any other major decisions on collective Allied policy be decided in his favour. Thus, the undoing of General Mihailović was one of the last acts that he would be able to claim as a victory "though it would end in a crushing defeat for the Chetniks". ${ }^{1}$

Glorification of the Partisans was taking place simultaneously with accusations that the Chetniks were involved in collaboration with Axis forces, in the main, with the Italian army. It is clear today that this tactic was initiated by Great Britain and then put into practice at a convenient moment. This was directly confirmed by Sir Ralph Skrine Stevenson, Envoy Extraordinary and Minister Plenipotentiary to the Kingdom of Yugoslavia. On February 25, 1944 he wrote to Orme Sargent, Permanent Under-Secretary of State for Foreign Affairs, about difficulties concerning General Mihailović. His information referred to the "secret history" of the SOE. Stevenson wrote that he heard from two independent sources that, eventually, when SOE was unable to deliver to Mihailović any supplies, they recommended to him to establish a most favourable arrangement with the Italians and obtain the arms from that source, if he could. Steven-

\footnotetext{
${ }^{59}$ Robert B. Asprey, War in The Shadows. The Guerrilla In History, volume I (USA: iUniverse, 2002), 345-346. Maclean himself suffered no illusions concerning Tito's political bent. He reported that ".. in any event, [Allied] help or not, the partisans were going to be a decisive postwar influence in Yugoslavia. Much will depend on Tito, and whether he sees himself in his former role of Comintern agent or as the potential ruler of an independent Yugoslav state." In Cairo, he explained this to British Prime Minister, and stressed the probability of Yugoslavia becoming a Communist state. Churchill's reaction underscored his priority concern for winning the war: "Do you intend," he asked, "to make Yugoslavia your home after the war?" "No Sir,", I replied. "Neither do I," he said. And, that being so, the less you and I worry about the form of Government they set up, the better. That is for them to decide." Quoted from: Fitzroy Maclean, Eastern Approaches (London: Jonathan Cape, 1949), 402-403.
}

${ }^{60}$ F. Maclean, Eastern Approaches, 303-532.

${ }^{61}$ J. A. S. Csehi, When Two Worlds Collide, 130. 
son also stressed that this story had been confirmed to him privately by and SOE agent. He expressed his fear that someday the British might be faced with a public statement of General Mihailović that he had the consent of, or was even induced to, collaborate with the British enemy. Stevenson concluded it would be worthwhile to destroy any written records to that effect that may still exist. ${ }^{62}$

When the policy towards Mihailović was changed, "collaboration with enemy" became the crucial argument for rejection, although no irrefutable evidence of the General's treason was proffered.

After learning that the Allies had abandoned the YAH, Mihailović tried to use the presence of American OSS officers, Lieutenant Colonel Albert Seitz and Captain Walter Mansfield to directly influence the American government and even sent a letter to President Roosevelt on December $28^{\text {th }}$, 1943, but without success. ${ }^{63}$ In the meantime, the first material assistance of real significance came from the Americans after Italy's surrender. Western military aid to Tito represented a distinct sacrifice, both in early stages, when arms and supply were measured in single tons and in delivery requirements of one or two aircraft, and later, when this aid measured thousands of tons delivered by squadrons of aircraft and ships. Military critics of the time, including some ranking officers, argued that this considerable investment in men and material could have been used more profitably. But, Maclean painted a glorious picture of an enormous Partisan army. Tito did not hesitate to exploit this opportunity. By early 1944 he was demanding tanks, artillery, and aircraft. ${ }^{64}$

The British Prime Minister met Tito on August 13, 1944 in Naples and reassured him of his commitment to the Partisan's cause. Churchill emphasized that he wanted reconciliation between Serbs and Partisans in order to create a united Yugoslav government. Tito insisted that he has "no quarrel" with the Serbs and promised not to introduce a Communist system in post-war Yugoslavia. ${ }^{65}$

Despite the massive support they now received in arms and ammunition, the Partisans accomplished remarkably little towards harassing and sabotaging the critical north-south lines of communication. As it turned out, the British, having abandoned Mihailović at the turn of the year, found themselves in August 1944 in the invidious position of having to supply an undisguised Partisan invasion of Serbia, directed overwhelmingly against Mihailović's forces.

\footnotetext{
${ }^{62}$ See Jovan Marjanović, Draža Mihailović između Britanaca i Nemaca (Zagreb-Beograd: Globus-Narodna knjiga-Prosveta, 1979), 219.

${ }^{63}$ NAW, SD, The White House Washington to the Secretary of State, March $13^{\text {th }}, 1944$.

${ }^{64} \mathrm{R}$. Asprey, War in The Shadows, 353.

${ }^{65}$ Tito said that reconciliation was unlikely between him and Mihailović, whose power rested on German and Bulgarian help. Churchill declared that the King should not be let down, to which Tito replied that he understood British obligations toward King Peter but was not able to do anything in that regard until after the war. Tito assured Churchill that he had no desire to introduce a Communist system into Yugoslavia. The Soviet mission with the Partisans, Tito said, had also spoken against the idea. When Churchill asked Tito whether he would make public his statement about communism in Yugoslavia, Tito demurred, saying it might seem to have been forced upon him. Quoted in W.R. Roberts, Tito, Mihailovic and the Allies, 245-246.
} 
Foreign Minister Eden remarked that Churchill was "somewhat disenchanted" by his meeting with Tito. In a memorandum to Eden on August 31 Churchill said that a great responsibility would rest on England after the war when all the arms in Yugoslavia, supplied by the West, would be in Tito's possession and could be used by him to subjugate the country. Eden noted in the memorandum that the Foreign Office hardly needed a reminder of this danger and that, in spite of its warnings, the Prime Minister himself had persistently "pushed for Tito". 66

Replying to Churchill, Eden wrote that British policy had been dictated on grounds of short-term military expediency rather than long-term political interest: "It was for this reason", he said, "that we for so long deprecated the policy of forcing the King to break with Mihailović before we had secured the position of the anti-communist Serbs in post-war Yugoslavia, and that we have for some time past been trying to bridge the gulf between the King and the Yugoslav Government-in-Exile on the one hand and the Partisans on the other, in the hope that by securing a united front we could prevent the arms we are giving to Tito from being used against his opponents when the day of liberation comes". 67

Eventually Mihailović lost his position in the Yugoslav Government-inExile. The British politicians were using all manner of political clout to get the young King Peter to turn over control of Yugoslavia to Tito, thereby losing his sovereignty. The British Foreign Office in February 1944 finally decided to remove Mihailović from the leadership of the Yugoslav resistance. All remaining British officers were recalled from Mihailović's headquarters and in May Churchill pressured the King to dismiss Božidar Purić's Yugoslav Government-in-Exile. The King dismissed this government on June 1, 1944 and named Croatian politician Ivan Šubašić as the new prime minister. ${ }^{68}$ That automatically removed Mihailović from his post of the minister of war. On August 29, 1944, King Peter signed an act of abolishing the High Command of the Yugoslav Army, so that Mihailović could not be its Chief-of-Staff. Finally, on September 12, 1944, King Peter, in a broadcast from London, called on all Yugoslavs to rally behind Tito.

The speech had an immediate and devastating effect on the morale of Mihailović and the Yugoslav Army in the Homeland. For more than three years they had fought for one thing above all: to save the monarchy and to return their King to a liberated country. Now the King, in so many words, branded them traitors. Meanwhile, the Soviet Red Army reached the Yugoslav border in September 6 and entered Bulgaria three days later.

Finally, in the Summer and Autumn of 1944 in Serbia, instead of a war of liberation, a horrible war was fought between Partisan and Chetnik forces. At the same time Churchill sharply rebuked Tito for using arms and ammunition supplied by the British Government to fight the Yugoslav people instead of

\footnotetext{
${ }^{66}$ Ibid, 247.

${ }^{67}$ Ibid, 248; see also E. L. Woodward, British Foreign Policy in the Second World War (London: Her Majesty's Stationery Office, 1962), 346.

${ }^{68}$ Since the beginning of 1942 Šubašić worked for the Soviet intelligence service (Aleksej Timofejev, Rusi i Drugi svetski rat u Jugoslaviji, Beograd: Institut za noviju istoriju Srbije, 2011, 274).
} 
fighting the enemy. But, Tito determined not to appear dependent on the West, flew to Moscow on September 21, 1944, where he met Stalin for the first time. They reportedly discussed plans for the final assault on Belgrade in October. Just as the Soviets had not wanted to alienate the British and the Americans, so the latter had wanted to prove to the Soviets that they were not averse to supporting another communist leader. This atmosphere worked to Tito's advantage and marked the beginning of his skilful balancing of the influences from the East and the West. ${ }^{69}$

On September 22 the first units of the Red Army, the $113^{\text {th }}$ Division of the Second Ukrainian front, crossed the Danube River from Romania, and entered Serbia. The Soviets came to the Partisans' assistance at the time of the liberation of Belgrade on October, 20, 1944, but were out of the country by the following month, leaving Tito to oversee final victory in May 1945. The Partisans, now equipped by the Soviets, were left to complete the task of eliminating the political opponents elsewhere in the country. By the summer of 1945 Yugoslavia had become a fully-fledged communist state - a one-party dictatorship with Tito as her overlord.

As noted by Pavlović, the fate of Yugoslavia was decided on the triangular relationship of the "Great allies", and the most important was a global agreement between the United States and the Soviet Union. For these reasons, Serbian politicians in exile could not understand why the US government did not react to obvious violence and violation of all democratic principles that they had always advocated. Although the US public was aware of the scale of the suffering of Serbs in the NDH, it was always emphasized that this was not an obstacle to the restoration of Yugoslavia on federal grounds. The concern for the fate of the Serbs did not given rise to any practical intervention in their favour. ${ }^{70}$

The US government deliberately created the illusion that Yugoslavia was not left to the Soviets, but a more autonomous resistance movement with a vague political orientation. All subsequent reports which verified the communist character of the Partisan movement; the clear intention of the Communist Party of Yugoslavia to take power in the country by all means; the direct hostility towards the United States; the reign of terror; the existence of an aggressive blend of nationalism and communism; the evidence that the new Yugoslav regime was copy of Soviet order; and that Tito was Moscow's best student, did not cause any reaction in the US administration. Simply, Yugoslavia was in the Soviet sphere of interest. ${ }^{71}$

Comparative analysis of British and American influence on the outcome of the Civil War and the post-war structure of Yugoslavia shows that sometimes apparent indifferences are more devastating and more significant than over commitment. The American military establishment decided that a

\footnotetext{
${ }^{69}$ V. Drapac, Constructing Yugoslavia, 159.

${ }^{70}$ Vojislav Pavlović, Od monarhije do republike. SAD i Jugoslavija 1941-1945 (Beograd, CLIOGlas srpski, 1998), 524.

${ }^{71}$ Ibid, 524-525.
} 
second front of Europe would not be opened in the Balkans. From this decision, President Roosevelt's conclusion was that Yugoslavia was to be left to the Soviet Union. Within this framework one can explain Churchill's efforts to retain some political influence in Yugoslavia. The US had led the sole care of their interests within the proclaimed principles of foreign policy. ${ }^{72}$

With the Partisans on the winning side, Tito established a communist regime. This regime collapsed in the wake of a renewed round of nationalist euphoria less than fifty years later, leading to the violent break-up of Yugoslavia in 1991. Aleksandar Petrovic concludes that the Allied switch of political and logistic support from the Chetniks to the Partisans in mid-1943 "set the stage for this chain of events". 73

\section{The Communist retaliation}

The Yugoslav wartime tragedy experienced its bloody epilogue in the spring of 1945. All non-communist military formations were being surrounded and destroyed. Contact with the West wasn't established and Partisan forces were in a hurry to take vengeance. These troops had a tragic destiny. ${ }^{74}$

The final retaliation over the defeated anti-communist formations was performed to a terrifying extent. Massive liquidations of the defeated forces were a characteristic for many nations at the end of Second World War. Historians that deal with that phenomenon have a tendency of stating that those who are glorified by war are also shamed by inhumane actions which were committed against unprotected people, inspired by alleged "higher purposes". The Yugoslav communists developed a well-organized policy of destruction of the "class enemy", regarded as "traitor of the nation". That way they were in effect combating any resistance against the Yugoslav communist regime.

The repercussions of war were more than horrible in Yugoslavia, and they were only increased by the after-war killings. By demonstrating "a revolutionary justice" a moral and biological core of the society was destroyed. There were execution sites and mass graves all over Austrian and Slovenian forests and mountains, with the most notable being at Bleiberg in Croatia, Zidani Most and Kočevski rog in Slovenia, and in Serbia. Such became metaphors for mass executions, but also for a tough moral defeat of the head of the Communist Party of Yugoslavia which was never admitted nor publicly declared. ${ }^{75}$

The final months of Yugoslav Army in the Homeland after the withdrawal from Serbia, have a certain tragic sense. The decisive battle between the Partisans and the Royalists was fought on May 13, 1945 on Zelengora. In the encounter with the several Partisan divisions, the Yugoslav Army in the Home-

\footnotetext{
${ }^{72}$ Ibid, 525-526.

${ }^{73}$ A. Petrovic, The Transformation of Mihailović's Chetnik Movement, 373.

${ }^{74}$ Kosta Nikolić, "The Yugoslav anticommunist forces at the end of the Second World War", Istorija 20. veka, 1, (2010), 103-118, 115.

75 See Kosta Nikolić, „Mač revolucije“. OZNA u Jugoslaviji 1944-1946 (Beograd: Službeni glasnik, 2013), 151-175.
} 
land suffered their last defeat. There were over 5,000 dead, wounded, and captured. Mihailović went into hiding as the new communist authorities started to search for him. On March 13, 1946 he was captured. ${ }^{76}$

On June 10, 1946, after nearly three months of interrogation, Mihailović was indicted for treason and collaboration with the Germans, and war crimes. Aleksandar Ranković and Milovan Đilas took over the task of formulating the prosecution case. To help blacken his name, Mihailović was tried alongside twentythree obvious collaborators with the Germans, including top official from Nedić's quisling administration. Mixing real traitors with alleged ones had been a common practice at the Moscow show trials of the 1930s, which Tito had witnessed. ${ }^{77}$

The atmosphere at the trial was extremely hostile towards Mihailović. The trial, highly staged and much publicized, lasted until July 15. Mihailović's final statement to the court on July 10 is illuminating: "Destiny was merciless towards me when it threw me into the most difficult whirlwinds. I wanted much, I began much, but the whirlwind, the world whirlwind, carried me and my work away" ${ }^{78}$

The verdict was "guilty"; the sentence, death. Mihailović's appeal for mercy was quickly rejected by the Presidium of the Yugoslav People's Assembly, and on July 17 he was executed by a firing squad. His place of burial has never been revealed to the public. It should be stressed that the trial was anything but a model of justice, as the stenographic record amply demonstrates. It is clear that Mihailović was not guilty of many the charges brought against him. ${ }^{79}$

Dragić Joksimović's defense of Mihailović was an honest defence and created a sensation in Belgrade. Joksimović got his degree in law at Belgrade University and his doctorate in Germany. In the interwar period he was a deputy in the Parliament and one of the leaders of Democratic Party. But, he was denounced as a "reactionary" by Tito himself, in a speech at Cetinje on July 16, 1946. Joksimović was arrested on June 16, 1949, charged with being a "people's enemy", and sentenced to three years in prison. He died while incarcerated on August 1, 1951 ${ }^{80}$ On May 15, 2015, General Mihailović was rehabilitated by the Higher Court in Belgrade. ${ }^{81}$

76 See Kosta Nikolić, Bojan Dimitrijević, „Zarobljavanje i streljanje generala Dragoljuba Mihailovića 1946. Nova saznanja o arhivskoj građi“, Istorija 20. veka, 2, (2009), 9-20.

77 Peter Batty, Hoodwinking Churchill. Tito's Great Confidence Trick (London: ShepheardWalwyn Publishers LTD, 2011), 263.

${ }^{78}$ Quoted in Kosta Nikolić, Bojan Dimitrijević, General Mihailović 1893-1946. Biografija (Beograd: Zavod za udžbenike, 2011), 499.

${ }^{79}$ See W.R. Roberts, Tito, Mihailović and the Allies, 307.

${ }^{80}$ Srđan Cvetković, Između srpa i čekića. Likvidacija „,narodnih neprijatelja“ 1944-1953 (Beograd: Službeni glasnik, 2015), 480-483.

${ }^{81}$ Blic, 16. 5. 2015. 


\section{REFERENCES}

- Asprey B., Robert. War in The Shadows. The Guerrilla in History, volume I. USA: iUniverse, 2002.

- Bailey, Roderick. "Communist in SOE: explaining James Klugmann's recruitment and retention". In The Politics and Strategy of Clandestine War. Special Operations Executive 1940-1946. Edited by Neville Wylie, 66-89. London and New York: Routledge Taylor \& Francis Group, 2007.

- Batty, Peter. Hoodwinking Churchill. Tito's Great Confidence Trick. London: Shepheard-Walwyn Publishers LTD, 2011.

- Burgwyn, James H. Empire on the Adriatic: Mussolini's Conquest of Yugoslavia 1941-1943. New York: Enigma Books, 2005.

- Catherwood, Christopher. The Balkans in World War Two. Britain's Balkan Dilemma. London: Palgrave Macmillan, 2003. https://doi.org/10.1057/ 9780230285880

- Catherwood, Christopher. Churchill and Tito: SOE, Bletchley Park and Supporting the Yugoslav Communist in World War II. Barnsley: Frontline Books, 2017.

- Csehi, Alan, Shambach. When Two Worlds Collide: The Allied Downgrading of General Dragoljub "Draža" Mihailović and Their Subsequent Full Support for Josip Broz "Tito". MA., Thesis. Kent State University, 2009.

- Churchill, Winston. The Second World War, volume III, The Grand Alliance. Boston: Houghton Mifflin Company, 1977.

- Cvetković, Srđan. Između srpa i čekića. Likvidacija „narodnih neprijatelja“ 1944-1953. Beograd: Službeni glasnik, 2015.

- Ćirković M. Sima. The Serbs. Carlton, Australia: Blackwell Publishing, 2004.

- Dimitrijević, Bojan. General Mihailović. Biografija. Beograd: A.L.X, 1996.

- Drapac, Vesna. Constructing Yugoslavia. A Transnational History. New York: Palgrave Macmillan, 2010.

- Đorđević, Dimitrije. Ožiljci i opomene, I. Beograd: BIGZ, 1994.

- Encyclopedia of Insurgency and Counterinsurgency. A New Era of Modern Warfare. Edited by Spencer C. Tucker. Santa Barbara, California; Denver, Colorado; Oxford, England: ABC-CLIO, LLC, 2013.

- Iaremko, Marta. "Belgrade Coup D'État of March 27". Proceedings of History Faculty of Lviv University, Issue 15, (2014), 119-128.

- Lampe R., John. Balkans into Southeastern Europe, 1914-2014. New York: Palgrave Macmilan, second edition, 2014. https://doi.org/10.1007/978-1-137-05777-8

- Maclean, Fitzroy. Eastern Approaches. London: Jonathan Cape, 1949.

- Manoschek, Walter. „Serbien ist judenfrei“. Militärische Besätzungspolitik und Judenvernichtung in Serbien 1941/42. München: Oldenbourg Verlag, 1995.

- Marjanović, Jovan. Draža Mihailović između Britanaca i Nemaca. Zagreb, Beograd: Globus-Narodna knjiga-Prosveta, 1979.

- Martin, David. The Web of Disinformation: Churchill's Yugoslav Blunder. New York: Harcourt Brace Jovanovich, 1990. 
- McCormick B. Robert. Croatia under Ante Pavelić. America, the Ustaše and Croatian Genocide. London \& New York: I.B Tauris, 2014.

- Milazzo J., Matteo. The Chetnik movement \& The Yugoslav resistance. Baltimor \& London: The Johns Hopkins University Press, 1975.

- Nikolić, Kosta i Milan Vesović. Ujedinjene srpske zemlje. Ravnogorski nacionalni program. Beograd: Vreme knjige, 1996.

- Nikolić, Kosta. Saveznici i pokreti otpora u Jugoslaviji 1941-1945. Beograd: Zavod za udžbenike, 2009.

- Nikolić, Kosta i Bojan Dimitrijević. „Zarobljavanje i streljanje generala Dragoljuba Mihailovića 1946. Nova saznanja o arhivskoj građi“. Istorija 20. veka, 2 (2009), 9-20.

- Nikolić, Kosta. "The Yugoslav anticommunist forces at the end of the Second World War", Istorija 20. veka, 1 (2010), 103-118.

- Nikolić, Kosta i Bojan Dimitrijević. General Mihailović 1893-1946. Biografija. Beograd: Zavod za udžbenike, 2011.

- Nikolić, Kosta. "Mač revolucije". OZNA u Jugoslaviji 1944-1946. Beograd: Službeni glasnik, 2013.

- Nikolić, Kosta. Istorija Ravnogorskog pokreta, I-II. Beograd: Zavod za udžbenike, 2014.

- Pavlaković, Vjeran. "Yugoslavia", in European Resistance in the Second World War. Eds. Philip Cooke and Ben H. Shepherd, 213-242. Barnsley: Pen \& Sword Praetorian Press, 2013.

- Pavlović, Vojislav. Od monarhije do republike. SAD i Jugoslavija 1941-1945. Beograd, CLIO-Glas srpski, 1998.

- Petrovic, Aleksandar. "The Transformation of Mihailović's Chetnik Movement: from Royalist Yugoslav Forces to Serb Nationalist Guerrillas". Ph. D. Thesis, Burnaby, British Columbia, Simon Fraser University, 2011.

- Radan, Peter. "Constitutional Experimentation and the National Question in Interwar Yugoslavia”, Istorija 20. veka, god. XXIX, br. 3 (2011), 25-38.

- Roberts, R. Walter. Tito, Mihailović and the Allies, 1941-1945. Durham: Duke University Press, second edition, 1987.

- Shepherd, Ben. Terror in the Balkans: German Armies and Partisan Warfare. Cambridge, Mass., Harvard University Press, 2012.

- Terzić, Velimir. Slom Kraljevine Jugoslavije 1941. Uzroci i posledice poraza, 2. Beograd: Narodna knjiga, 1983.

- Timofejev, Aleksej. Rusi i Drugi svetski rat u Jugoslaviji. Beograd: Institut za noviju istoriju Srbije, 2011.

- Tomasevich, Jozo. The Chetniks. War and Revolution in Yugoslavia, 19411945. Stanford, California: Stanford University Press, 1975.

- Trew, Simon. Britain, Mihailović and the Chetniks, 1941-42, London: Macmillan, 1998. https://doi.org/10.1057/9780230389762

- Trifković, Srdja. "Prince Pavle Karardjordjević". In: The Serbs and their leaders in the Twentieth Century. Eds. Peter Radan and Aleksandar Pavković, 158-202. Sidney: Ashgate, 1997. 
- Yungblyud, Valerij Teodorovich i Aleksej Aleksandrovich Kostin,. "Amerikanskoe vospriyatie Sovetskoj politiki v otnoshenii Yugoslavii v 1942-1945". Izvestiya Ural'skogo federal'nogo universiteta, Tom 120, no. 4 (2013), 71-85.

-Williams, Heather. Parachutes, Patriots, and Partisans. The Special Operations Executive and Yugoslavia, 1941-1945. London: C Hurst \& Co Publishers Ltd, 2003.

- Wheeler, Mark. "Resistance from abroad: Anglo-Soviet efforts to coordinate Yugoslav resistance, 1941-1942“. In: Special Operations Executive. A new instrument of war. Edited by Mark Seaman, 103-122. London and New York: Routledge Taylor \& Francis Group, 2006.

- Woodward, E. L. British Foreign Policy in the Second World War. London: Her Majesty's Stationery Office, 1962.

KOSTA NIKOLIĆ, PhD, Principal Research Fellow

Institute of Contemporary History

Belgrade, Republic of Serbia

kostasnikolic@yahoo.com

NEBOJŠA STAMBOLIJA, Assistant Researcher

Institute of Contemporary History

Belgrade, Republic of Serbia

nstambolija@yahoo.com

\author{
ROYALIST RESISTANCE MOVEMENT \\ IN YUGOSLAVIA IN THE SECOND WORLD WAR
}

\title{
Summary
}

The nucleus of what later became royalist resistance force was a small group of officers and non-commissioned officers of the Yugoslav royal army who refused to surrender. Under the command of General Staff Colonel Dragoljub Mihailović these men retreated into the hills and started marching to the mountainous interior of Serbia where they hoped to find other parts of the Yugoslav army whom they would join and with whom they would continue the fight against the enemy. Mihailović and his men gathered at the plateau of Ravna Gora in Western Serbia on May 11, 1941. In the first days of creation of the resistance movement, Mihailović pointed out the need of secret organizing, civil disobedience and harmfulness of early actions. Creation of a new military organization, called Yugoslav Army in the Homeland, was finished in June 1942. The new military organization was based on territorial principles, so to avoid reprisals, but in readiness for the final operations at the "appropriate time".

The Royalist movement was a traditional royalist and national Serb force. Despite the official Yugoslav label and the participation of some nonSerbs, the Royalists were essentially a Serb national force from the beginning. This does not mean that the Royalists were anti-Yugoslav as such, or that they 
did not want to restore Yugoslavia - albeit on their own terms - after the war. Rather, this meant that a Serb affair, such as the creation of a Serb territorial unit, was the first priority for the Royalist. During Second World War were three parallel conflicts in occupied Yugoslavia. First, a resistance struggles against the Axis, second, a communist-royalist civil war and third, a regional ethnoreligious conflict made possible by the wartime circumstances. The Yugoslav Army in the Homeland fought in all three: as the extension of the Yugoslav army in the resistance struggle, in the civil war as royalists, and in the ethnoreligious conflict as a Serb territorial force in areas with a mixed population. Once combined, these elements paint a picture of Mihailović's wartime resistance movement as an anti-communist, royalist, Serb territorial military force in areas with a heterogeneous population, and an anti-communist royalist guerrilla in Serbia and Montenegro.

In their policies towards Yugoslavia, each of the three Allied Powers had their short-term and long-term goals. The short-term goals were victory over the Axis powers. The long-term goals were related to the post-war order in Europe (and the world). The Allies were unanimous about the short-term goals but differed in respect to long-term goals. The relations between Great Britain and the Soviet Union were especially sensitive: both countries wanted to use a victory in the war as a means of increasing their political power and influence. Yugoslavia was a useful buffer zone between British and Soviet ambitions, as well as being the territory in which the resistance to the Axis was the strongest. This was the starting point of a long and complex process that led to the destruction of the social and political order of the Kingdom of Yugoslavia and the introduction of communist dictatorship at the end of the war.

The Second World War caused both the making and the unmaking of the Yugoslav army in the Homeland. In the autumn of 1944 it was defeated in Serbia. The outcome of the civil war had been decided by the arrival of the Red Army. Mihailović withdrew with the majority of his forces to Bosnia in an unrealistic hope that the ideological conflict between the West and the Soviets might bring certain changes. Seeing himself as the saviour of the Serbian people, the defender of King and Homeland, Mihailović chose there to make a new effort to defeat the "Communist enemy" rather than be evacuated.

This was the major miscalculation which would lead the Royalist movement to its final collapse. The decimated units, some 25,000 men, moved towards in last battleground in Bosnia. So, the Yugoslav Army in the Homeland, which had been the initiator of armed resistance against the occupying forces, ended up defeated, sharing the fate of their German foes that had been intent on destroying them during the war.

KEYWORDS: Yugoslavia, resistance, Chetniks, military strategy, communist ideology, Allies, Second World War, General Dragoljub Mihailović 